Bulletin of the Natural History Museum, 2015, 8: 49-74.

Received 05 Aug 2015; Accepted 11 Dec 2015.

doi: $10.5937 / \mathrm{bnhmb} 1508049 \mathrm{~N}$

UDC: 582.681.26(497); 582.681.26(292.451/.454)

Original scientific paper

\title{
VIOLA CHELMEA AND VIOLA JOOI(VIOLACEAE), NEW SPECIES FOR THE FLORA OF SERBIA AND THEIR DISTRIBUTION IN THE BALKAN PENINSULA AND THE CARPATHIANS
}

\author{
MARJAN NiKeTIĆ ${ }^{1}$, PAVle CiKOVAC ${ }^{2}$, ZOLTÁN BARINA ${ }^{3}$, DÁNIEl PIFKÓ ${ }^{3}$, \\ LJUPČO MELOVSKI ${ }^{4}$, ŠEMIJA DURAKI ${ }^{5}$, GORDANA TOMOVIĆ ${ }^{6}$ \\ ${ }^{1}$ Natural History Museum, 11000 Belgrade, Serbia, e-mail: mniketic@nhmbeo.rs \\ ${ }^{2}$ Landwirtschaftskammer Nordrhein-Westfalen, Bonn, Siebengebirgsstr. 200, \\ D-53229 Bonn, Germany, e-mail: pavle_cikovac@yahoo.com \\ ${ }^{3}$ Hungarian Natural History Museum, Department of Botany, P.O. Box 137, 1431 \\ Budapest, Hungary, e-mail: barina@bot.nhmus.hu; pifko@bot.nhmus.hu \\ ${ }^{4}$ Institute of Biology, Faculty of Natural Sciences and Mathematics, Sts. Cyril and \\ Methodius University, Arhimedova 5, 1000 Skopje, Republic of Macedonia, \\ e-mail: melovski@pmf.ukim.mk \\ ${ }^{5}$ Eight Belgrade Grammar School, Grčića Milenka 71, 11000 Belgrade, Serbia, \\ e-mail: semijaduraki@gmail.com \\ ${ }^{6}$ Institute of Botany and Botanical Garden, Faculty of Biology, University of \\ Belgrade, 11000 Belgrade, Serbia, e-mail: gtomovic@bio.bg.ac.rs
}

During several botanical expeditions in the Republic of Serbia (Mts ŠarPlanina and Mts Homoljske Planine), two species of the genus Viola ( $V$. sect. Viola) were found as new for the flora of Serbia: Viola chelmea Boiss. \& Heldr. in Mt. Ošljak and $V$. jooi Janka in Mt. Vukan. The last taxon represents a new species also for the flora of the Balkan Peninsula. The taxonomic positions, phytogeographic importance and conservation statuses of the two new plants is discussed within the scope of their newly established distribution patterns both in the Carpathians and the Balkan Peninsula.

Key words: vascular flora, Viola chelmea, Viola jooi, distribution, Serbia, Balkan Peninsula, Carpathians 


\section{INTRODUCTION}

Viola $\mathrm{L}$. is one of the most intriguing genus of the flora of the Balkan Peninsula and consist of ca 90 species classified into five sections (Beck 1918, Rohlena 1942, Valentine et al. 1968, Erben 1985, Qosja et al. 1992, Micevski 1995, Assyov et al. 2012, Dimopoulos et al. 2013, Tomović et al. 2014, Nikolić 2015, http://www.theplantlist.org/). The highest number of Viola species in the Balkans was recorded in Greece - 60 species (Dimopoulos et al. 2013), then in Republic of Macedonia - 41 species (Micevski 1995) and in Bulgaria - 38 (Assyov et al. 2012). In the flora of Serbia, the most recent survey of the herbarium data revealed the presence of 27 species belonging to three sections: V. sect. Viola ("Nominium"), $V$. sect. Dischidium Ging. and $V$. sect. Melanium Ging. (Tomović et al. 2014).

Still, the number of Viola species is not final, since the intensive and long-standing field work and inspection of the herbarium collections resulted in discovering of two new species from the $V$. sect. Viola either for the whole Balkan Peninsula or for the territory of Serbia. The first one is $V$. chelmea Boiss. \& Heldr. collected on Mts Šar-Planina in Metohija province and second is $V$. jooi Janka that was discovered in Mts Homoljske Planine in northeastern Serbia. New findings and complete distribution range of $V$. chelmea in the Balkan countries (Croatia, Bosnia and Herzegovina, Montenegro, Albania, Republic of Macedonia and Greece) and V. jooi in the Carpathians (Romania and Ukraine) are also provided.

\section{MATERIAL AND METHODS}

Field survey, checking and revision of herbarium material and numerous literature sources were used for compilation of the distribution records. Distribution of the species in the Balkan Peninsula and Southeastern Europe is presented according to the grid map with squares of $10 \times$ $10 \mathrm{~km}$, based on the Military Grid Reference System (MGRS) projection (Lampinen 2001). Collected plant material is stored in the Herbarium of the Institute of Botany and Botanical Garden "Jevremovac", University of Belgrade (BEOU), the Herbarium of the Natural History Museum in Belgrade (BEO), Hungarian Natural History Museum, Budapest (BP) and Herbarium Melovskiorum, Skopje, Republic of Macedonia (MKMEL), (THIERS 2013, http://sciweb.nybg.org/ Science2/Index-Herbariorum.asp). Nomenclature is given according to The Plant List database (http://www.theplantlist.org). Taxon description is given according to several botanical sources (Grințescu et al. 1955, Valentine et al. 1968, Raus 1986, Micevski 1995, Nikolić et al. 2015, https://de.wikipedia. org/wiki/Viola_chelmea), with some modifications and changes which were the results of the field observations. Plant material for morphological 
analysis included 40 individuals collected from 11 localities in Bosnia and Hercegovina, Montenegro, Serbia, Republic of Macedonia and Greece). Descriptive statistics and analysis of variance were performed.

\section{RESULTS AND DISCUSSION}

Viola chelmea Boiss. \& Heldr. in Boiss., Diagn. P1. Or. Nov. ser. 2, 1: 54 (1854).

\section{DESCRIPTION}

Perennial, 2.5 to $8 \mathrm{~cm}$, acaulescent, herbaceous plant, with short, lignifying and thick erect rhizome, without stolons, often covered by withered leaf bases. Leaf petiole 4-5 cm long, (0.8-)1.4-1.9(2.4) times longer than lamina; leaf blade triangular to ovate-oblong, obtuse, cuneate, truncate or at most very shallowly cordate at the base (1.2-)1.4-4.6(-5.2) $\mathrm{cm}$ long, (1.0-)1.1-2.4(-3.0) cm wide, hairy when young, later becoming glabrous. Stipules broadly lanceolate, shortly glandular-fimbriate. Peduncles 3-8 cm long. Flowers small (1 cm in diameter), not fragrant. Sepals ovate, obtuse or subacute, glabrous. Petals pale violet, violet or whitish-violet; lower petal including spur 1-1.4 cm long. Spur rather stout, shorter than sepals. Fruiting peduncles mostly remaining upright, or those of cleistogamous flowers lying on the ground when ripe. Capsule glabrous. Flowering period: (April-) May-July.

\section{TAXONOMIC MEMBERSHIP}

Viola [subsect. Viola] ser. Eflagellatae Kitt. ex Kupffer, Oesterr. Bot. Z. 53(8): 328 (1903). - Typus: Viola hirta L.

- Viola [infragen. unranked] Eflagellatae Kitt. ex Juz., Taschenb. Fl. Deutschl., ed. 2: 934 (1844), nom. inval.

- Viola subsect. Eflagellatae (Kitt. ex Juz.) Espeut, Monde P1. 464: 37 (1999), comb. inval.

incl. Viola [infragen. unranked] Lignosae W. Becker, Beih. Bot. Centralbl., Abt. 2. 21(1): 1 (1910).

Viola chelmea was originally described from Mt. Chelmos (Peloponnisos, Greece). As a leading authority on the genus in early $20^{\text {th }}$ century W. Becker (1910) separated endemic Balkan ( $V$. chelmea) and Lebanese ( $V$. libanotica Boiss.) species (into unranked "Lignosae") from typical acaulescent representatives of the genus $(V$. subsect. Viola, named as unranked "Curvato-pedunculatae" or "Uncinatae" - incl. V. odorata L., $V$. alba Besser, $V$. hirta L., $V$. pyrenaica Ramond ex DC., etc.). The same author later joined two Balkan ( $V$. prenja Beck, $V$. vilaensis Hayek) and one Afghan (V. griffithiana Boiss.) violets to "Lignosae" (Becker 1925). Thereafter five species were described from Turkish mountains $(V$. 
sandrasea Melch., V. isaurica Contandr. \& Quézel, V. bocquetiana Yıld., $V$. kizildaghensis Dinç \& Yıld., V. yildirimlii Dinç \& Bağcı) which also apparently belong to this group (Dinç 2009), although Nikitin (2012) treat $V$. sandrasea conspecific with $V$. pyrenaica. The main diagnostic features of "Lignosae" (compared to $V$. subsect. Viola) are branched, thickened and woody rhizome covered by withered leaf bases at the top, cuneate to slightly cordate leaf blades, uncinate stigmas with horizontal to more upwardly directed beaks as well as erect fruiting peduncles (Becker 1925). In florogenetic respects, representatives of "Lignosae" are exclusively oromediterranean or subalpine-zone heliophytic relict species with disjunct distribution, restricted to separate centres of speciations in the East Mediterranean (s.1.) and Orient. Melchior (1939) and Schmidt (1964) also pointed out that it is a primitive group compared to the $V$. subsect. Viola ["Acaules"]. On the contrary, Marcussen et al. (2003) noted the presence of some derived characters shared with typical taxa of $V$. subsect. Viola (uncinate style, unexplosive capsule).

Melchior (1939), Rössler (1943) and Schmidt (1964) partially rejected Beckers's classification of "Lignosae" proposing reinclusion in $V$. subsect. Viola, i.e., $V$. ser. Eflagellatae, and anatomical (absence of excretory cells), morphological (style, seeds) and karyological evidences supported this attitude. Some of these authors believed that representatives of "Lignosae" should be classified in a separate series, closely related to $V$. ser. Eflagellatae, but they did not apply a formal designation. This concept follows the vast majority of modern authors, not mentioning (Valentine et al. 1968, Marcussen \& Borgen 2000, Dinç \& Yildirimli 2002, Dinç et al. 2003, Bağc1 et al. 2008) or mentioning "Lignosae" (Okamoto et al. 1993, Marcussen et al. 2003, Dinç 2009). Marcussen et al. (2003) even expressed doubts on monophyly of "Lignosae", considering it as an ecological group adapted to drought and exposure. In support of this conclusion, these authors pointed to the occurrence of spontaneous fertile hybrids of $V$. chelmea with $V$. alba and $V$. odorata (from $V$. ser. Viola), and allozyme studies also showed connection of $V$. chelmea with $V$. hirta and $V$. ambigua Waldst. \& Kit. (from $V$. ser. Eflagellatae) (Marcussen et al. 2003). We have also noticed a great similarity between Dinaric-Scardic representatives of $V$. chelmea and Pontic $V$. ambigua, which are allopatric and possibly vicariant in the Balkan Peninsula (see also Raus 1986). On the other hand, morphological singularity of the group "Lignosae" (Becker 1925) can not be ignored, and in the case of the recognition of this group $V$. chelmea (incl. $V$. vilaensis) would have been the only European species. However, instead of a formal designation of its rank it is better to wait for the results of phylogenetic studies at this point. Eurasian $V$. collina Besser, $V$. thomasiana Songeon \& E.P. Perrier (from the Alps and Caucasus) and $V$. hondoensis W. Becker \& H. Boissieu (from Japan) are also included in $V$. ser. Eflagellatae (Becker 1925). 
GENERAL DISTRIBUTION

$V$. chelmea is Balkan endemic plant, distributed in Croatia, Bosnia and Herzegovina, Montenegro, Albania, Republic of Macedonia and Greece (Fig. 1). Within the species, two subspecies were recognized (Valentine et al. 1968, https://de.wikipedia.org/wiki/Viola_chelmea):

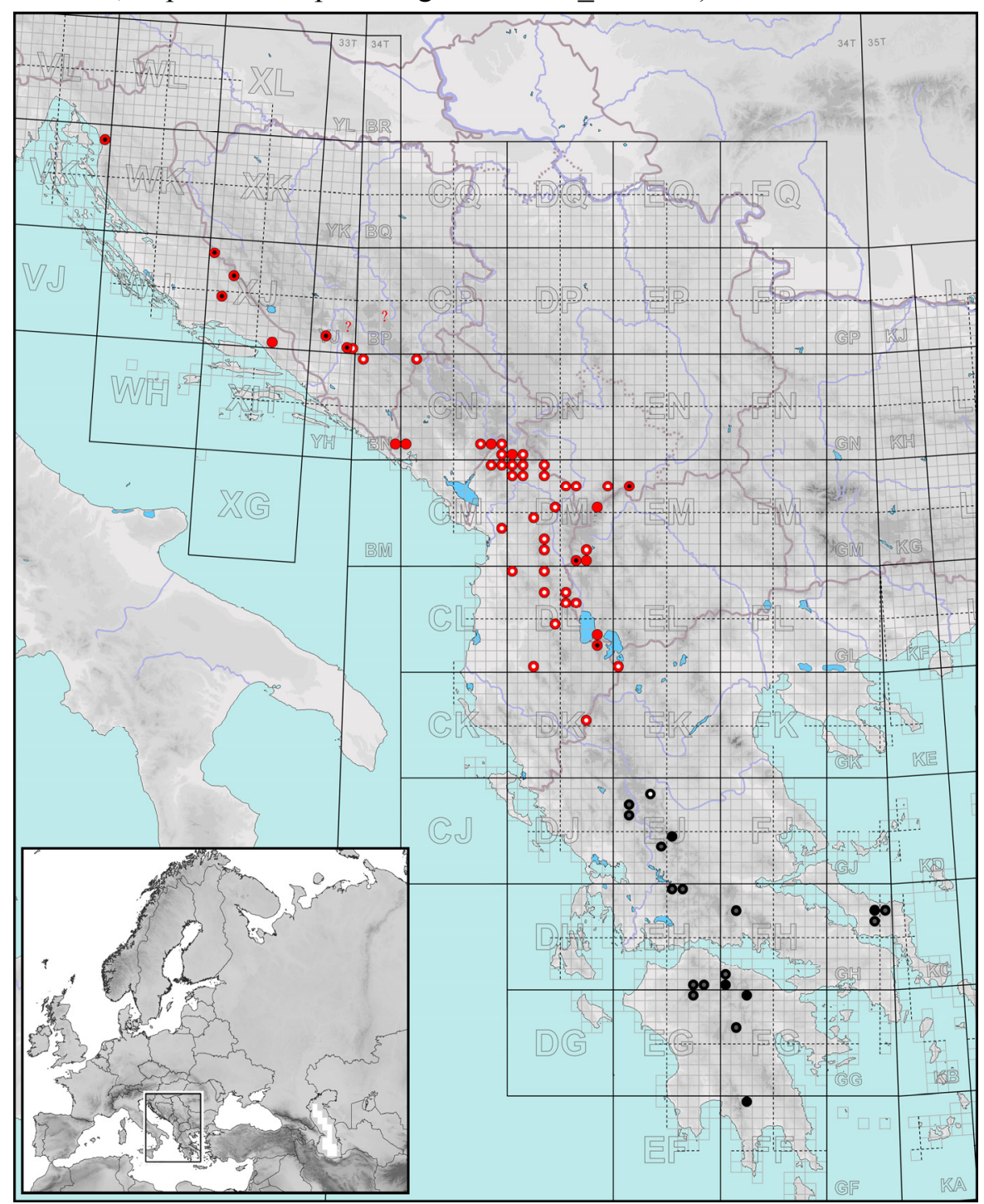

Fig. 1. - Distribution of the species Viola chelmea Boiss. \& Heldr. in the Balkan Peninsula. V. chelmea subsp. vratnikensis Gáyer \& Degen (red marks), $V$. chelmea subsp. chelmea (black marks); indication of locations: full circle according to literature and herbarium data; circle with white spot - according to herbarium new chorological data only; circle with gray/black spot - according to literature data only; ? - doubtful records ( $V$. prenja Beck). 


\section{subsp. chelmea}

Leaf blade $1.4-2.2 \times 1.1-1.5 \mathrm{~cm}$; broadly triangular to reniform, $1.1-1.4$ as long as wide; truncate to shallowly cordate, less frequently cuneate at base; margins distinctly crenate, with 8-10 teeth on each side (Fig. 2). Stipules \pm scarious, subglabrous on the upper surface. Bracts of the peduncle narrow, glabrous or sparsely ciliate. Petals pale violet.

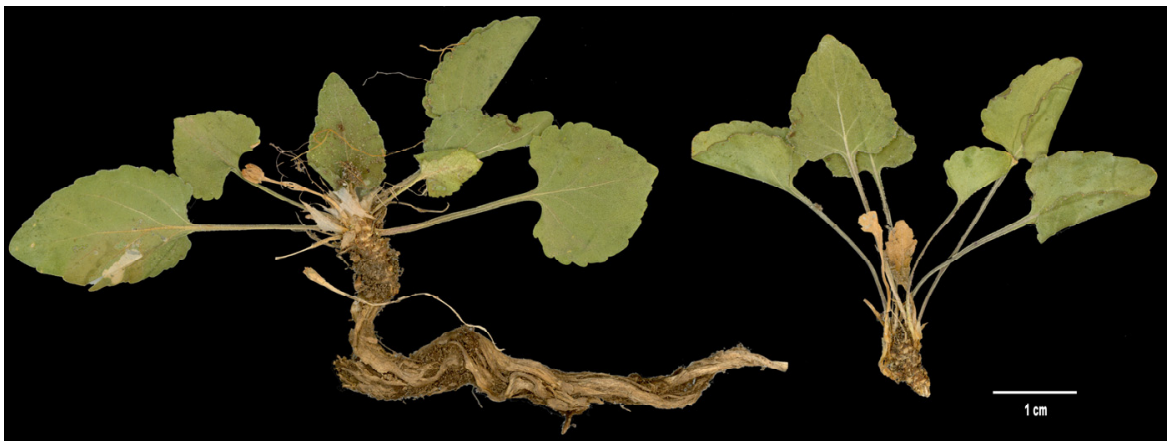

Fig. 2. - Viola chelmea Boiss. subsp. chelmea - herbarium specimens from Mt. Chelmos (Peloponnisos, Greece) (BEO).

DISTRIBUTION

Present only in Greece (Fig. 1) in the following regions and localities: South Pindhos (Mt. Athamanon, Mt. Liakoura, Mt. Pteri, Mt. Tsoumerka, Mt. Voutsikáki), Sterea Ellas (Mt. Chelidon, Mt. Dhirfis, Mt. Giona, Mt. Kalliakóuda, Mt. Xirovouni) and Peloponnisos (Mt. Chelmos, Mt. Erymanthos, Mt. Killini, Mt. Menalon, Mt. Taygetos) (Raus 1986, Tan \& Iatrou 2001).

NEW CHOROLOGICAL RECORDS

Greece: Thessaly: Mt. Tringía, above village Palaiochóri, 39.58711 N, 21.39467 E, [MGRS 34T EJ38], on limestone rocks, 1945 m, 23.06.2015, coll./det. Z.Barina(BP 27873).

subsp. vratnikensis Gáyer \& Degen, Magyar Bot. Lapok 13: 309 (1914)

$\equiv V$. chelmea var. vratnikensis (Gáyer \& Degen) Hayek, Denkschr. Akad. Wiss. Math.-Nat. Kl. (Wien) 94: 154 (1918) $\equiv V$. dinarica Trinajstić Trinajstić, Suppl. Fl. Anal. Jugosl. 3: 6 (1975), nom. illeg. (nom. superfl. for $V$. vilaensis Hayek).

$=V$. vilaensis Hayek, Denkschr. Akad. Wiss. Math.-Nat. K1. (Wien) 94: 154, Plate 3 (Fig. 1), Plate 5 (Fig. 8) (1918); $\equiv V$. dinarica subsp. vilaensis (Hayek) Trinajstić, Suppl. Fl. Anal. Jugosl. 3: 6 (1975), nom. illeg. 
Leaf blade 3.8-4.6 × 2-2.4 cm; narrowly triangular, 1.7-1.9 as long as wide; cuneate to truncate, rarely shallowly cordate at base; margins finely serrate-crenate, with 13-15 teeth on each side (Figs 34). Stipules not scarious, greenish, purplish or brownish, often pubescent on the upper surface. Bracts of the peduncle wide at the base, ciliate. Petals violet (Fig. 3 a-b) to whitish-violet (Fig. 3 c-d).

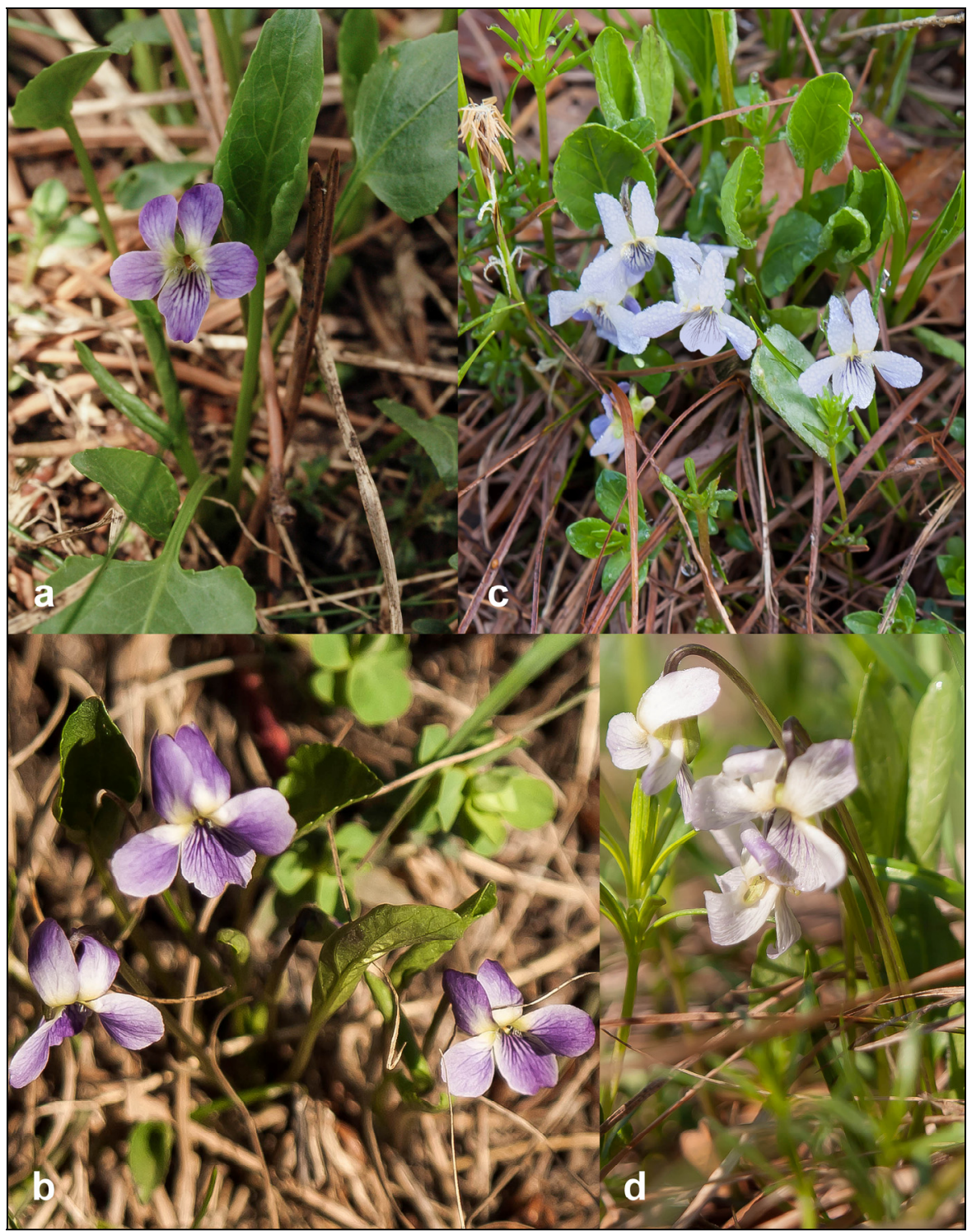

Fig. 3. - Viola chelmea subsp. vratnikensis Gáyer \& Degen in flower: a) plant from Mt. Orjen, Zubački Kabao (SW Montenegro); b-d) plants from Mt. Bijela Gora (SW Montenegro) (photo P. Cikovac). 


\section{VARIABILITY AND MORPHOLOGICAL DIFFERENTIATION}

Subspecies was originally described from Mt. Velebit (in Croatia) and Mt. Orjen (Montenegro) (Degen 1914), wherein the elder G. Beck's exsiccate from Mt. Velež (Bosnia and Hercegovina) was incorrectly treated as a type subspecies. Longer ciliate margins of stipules with finely fringed cilia (compared to the type subspecies) is used as the main diagnostic character in the protologue and this judgment is also currently accepted (Valentine et al. 1968, Trinajstić 1975, The Plant List 2013). However, it is excluded from our identification key as too variable. Four years after Degen's discovery, Hayek (1918) described $V$. vilaensis from the border of

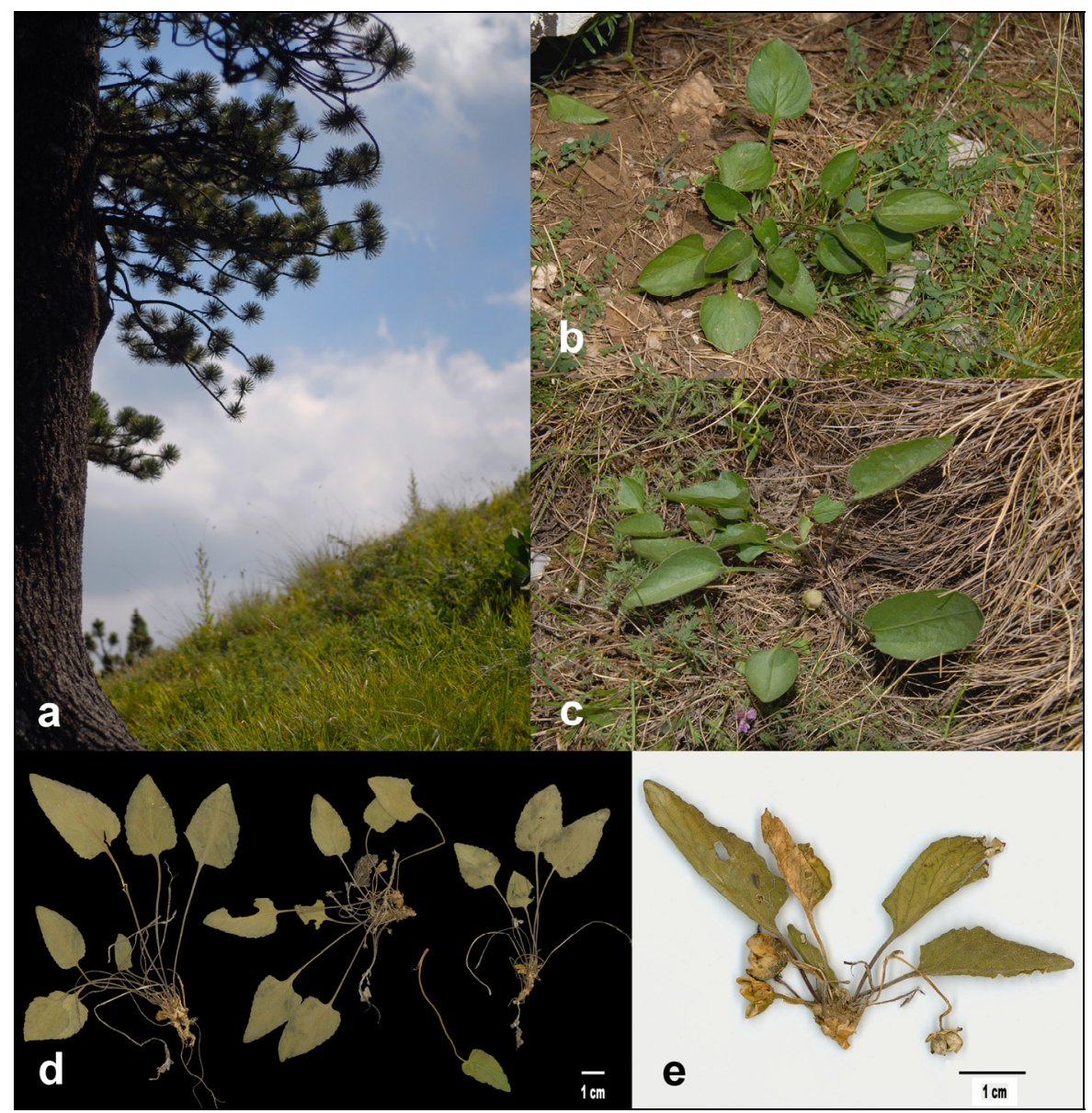

Fig. 4. - Viola chelmea subsp. vratnikensis Gáyer \& Degen in fruit: a) Mt. Ošljak, Popovo Prase (S Serbia, Metohija) - species habitat; b-c) plants from Mt. Jablanica, Malo Sedlo (SW Macedonia); d-e) herbarium specimens from Mt. Jablanica, Malo Sedlo (SW Macedonia) (BEO) (photo M. Niketić). 
Montenegro and Albania (Mt. Kučke Prokletije). He distinguished it from $V$. chelmea (incl. V. c. subsp. vratnikensis) by leaf blade base more cuneate to truncate (rarely shallowly cordate), hairy young leaves, pubescent stipules and paler petals. With the exception of leaf indumentum, we accept these diagnostic features, but they do not apply to the analysed populations from Mt. Orjen (V. c. subsp. vratnikensis) and Hayek's and Degen's plants obviously belong to the same taxon. The results of our morphometric analysis additionally support the proposed subspecific delimitation and the most significant and easily recognizable features refer to the leaf blade size, shape and serration. The type subspecies has conspicuously smaller and relatively broader blades with more prominent and fewer teeth on the margin (Fig. 5), as well as \pm scarious stipules. These differences are not mentioned in the existing literature. Analysis of variance showed that petiole/blade ratio has no role in the subspecific
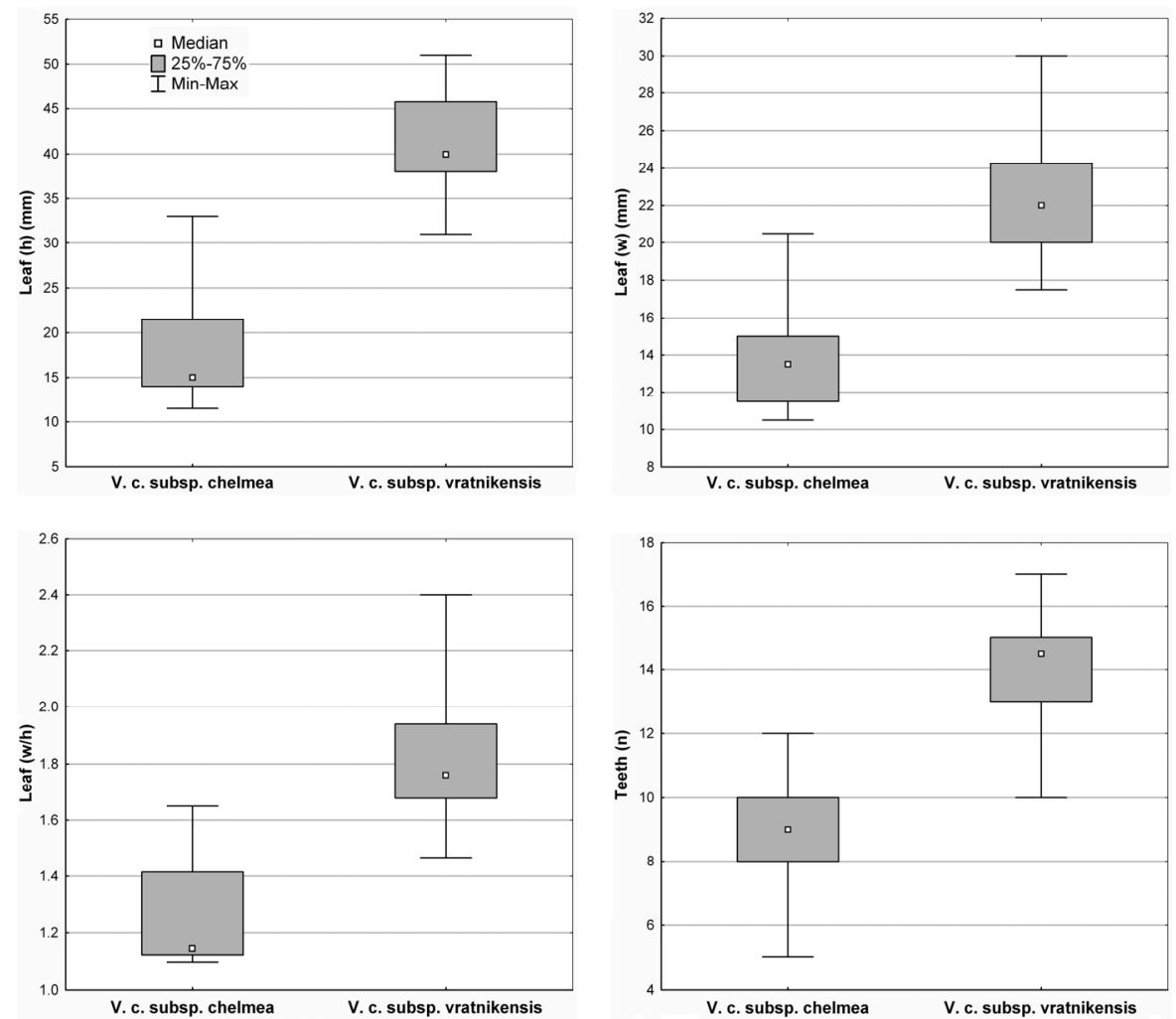

Fig. 5. - Variation in selected morphological characters and indices (leaf blade height, leaf blade width, leaf blade length/width, numbers of teeth on one side of leaf blade margin) for Viola chelmea Boiss. subsp. chelmea and V. chelmea subsp. vratnikensis Gáyer \& Degen. 
differentiation. Observed differences may point to the specific status of non-Greek taxon (Trinajstić 1975, Raus 1986) - in that case the legitimate name would be $V$. vilaensis, not $V$. dinarica. However, transitory forms are also observed in some populations of V. chelmea (e.g. Mt. Voutsikáki in S Pindhos, BEO).

\section{TAXONOMIC RELATIONSHIPS}

Currently, $V$. vilaensis is included in the $V$. chelmea subsp. vratnikensis (Valentine et al. 1968, Marcussen et al. 2003, The Plant List 2013). On the other hand, the position of closely related $V$. prenja is still unresolved. Beck (1887) described $V$. prenja from Mt. Prenj in Herzegovina province (Bosnia and Herzegovina) and presented detailed description and drawing of this taxon, as well as habitat type ["in rupium fissuris"] in which this taxon was found. According to Beck (1918) there is only a single gathering from this locality. Later on, Beck (1901) added new locality for this taxon in Mt. Treskavica but Bjelčić \& Šilić (1971), Šilić \& Abadžić (1991) and Đug et al. (2013) cited Mt. Prenj as unique locality for this plant.

Identity of this plant has been challenged on several occasions. After the comparison of $V$. chelmea subsp. vratnikensis and $V$. prenja, Degen (1914) concluded that they are "extremely close" and "appear to be local hybrids of the same species". According to this author, the plants from Mt. Orjen are very similar to $V$. prenja and Beck's plant only differs by elongated rhizome, narrower not deeply fimbriate stipules, fragrant flowers and thicker, slightly upwardly curved spur. Moreover, Degen's material from Mt. Orjen was previously identified as $V$. prenja.

In contrary, Hayek $(1918,1924)$ claimed that the whole habitus of $V$. prenja (particularly rhizome) does not indicate belonging to the same taxonomic group as the $V$. chelmea. According to him this plant is actually closely related to $V$. pyrenaica and insignificant differences between the two taxa ( $V$. prenja has smaller flowers and thicker spur) refer to their conspecific status. Malý (1923) considered it as a variety of $V$. pyrenaica. This opinion is accepted also currently (Valentine et al. 1968, Trinajstić 1975, The Plant List 2013), although Becker (1925) included it in the "Lignosae".

It is not easy to choose which of these two classification is correct due to lack of type material originated from single gathering. Furthermore, the original illustration may correspond to both aforementioned species ( $V$. chelmea and $V$. pyrenaica). Nevertheless, in the protologue $V$. suavis [sub V. austriaca A. Kern. 
$\&$ Jos. Kern.] and $V$. odorata were suggested as closest relatives of $V$. prenja (Beck 1887). Although $V$. pyrenaica has traditionally been classified in $V$. ser. Eflagellatae, recent allozyme studies showed that $V$. pyrenaica is possibly ancestor of $V$. suavis from $V$. ser. Viola (Marcussen \& Borgen 2000). Taking into account other characteristics (rhizome, stipules, fragrant flowers) $V$. prenja appears to be linked with $V$. pyrenaica. However, Beck (1887) also mentioned the lower stature of the plant, small leaves, truncate to shallowly cordate at base and small flowers. For these reasons, and taking into account phytogeographic characteristics of the area, a possible relationship with $V$. chelmea should not be excluded. Therefore, on the distribution map of $V$. chelmea (Fig. 1) two records for $V$. prenja are treated as doubtful.

\section{DISTRIBUTION}

Distributed in Croatia: Mt. Velebit - Vratnik peak - locus classicus, Mt. Dinara, Mt. Svilaja and Mt. Biokovo (Nikolić 2015, Nikolić et al. 2015 sub. V. dinarica Trinajstić), Bosnia and Herzegovina: Mt. Dinara, Mt. Čabulja and Mt. Velež - western parts (Beck 1887, 1901, 1918, Degen 1914, Bjelčić \& Šilić 1971, Šilić \& Abadžić 1991, Đug et al. 2013 (sub. V. dinarica Trinajstić), Lubarda 2013), Montenegro: Mt. Orjen (Degen 1914), Mt. Kučke Prokletije (Rohlena 1942, Valentine et al. 1968, sub. V. vilaensis Hayek), Albania: Mt. Grammos and Mts Bjeshkët e Namuna (Barina \& Pifkó 2007) and Prespa Park (Shuka 2012) and Republic of Macedonia: Mts Šar-Planina, Mt. Bistra, Mt. Dešat, Mt. Galičica (Micevski 1995), Mt. Jablanica, without precise localities (https://de.wikipedia.org/wiki/Viola_chelmea) (Fig. 1).

\section{NEW CHOROLOGICAL RECORDS}

Serbia (first record): Metohija: Mts Šar-Planina, Mt. Ošljak, Popovo Prase peak, [MGRS 34T DM97], stene i kamenjari, krečnjak, c. 1900 m, 30.07.2008, coll. M. Niketić, Š. Duraki, det. M. Niketić (BEO s.n.).

Bosnia and Herzegovina: Mt. Velež, Veliki Velež, Ćaba peak, [MGRS 34T BN69], visokoplaninski pašnjaci i kamenjari, krečnjak, 1200-1750 m, 08.08.2011, coll./det. M. Niketić (BEOU 337705; BEO s.n.); Mt. Velež, Veliki Velež, between Ćaba peak and Botun peak, [MGRS 34T BN69, BP50], visokoplaninski pašnjaci i stene, krečnjak, 1750-1900 m, 08.08.2011, coll./det. M. Niketić (BEO s.n.); Mt. Maglić, Prijevor peak, [MGRS 34T CN19], visokoplaninski pašnjaci i kamenjari, krečnjak, 1800-2000 m, 12.08.2008, coll./det. M. Niketić (BEO s.n.).

Montenegro: Mt. Orjen, Krivošije, [MGRS 34T CN01], 19.06.1906, coll./det. J. Schneider, sub. V. vratnikensis (W 9473); Mt. Orjen: Krivošije, [MGRS 34T CN01], kalk, c. 1850 m, 09.06.1911, coll. J. Baumgartner (WU 5274); Mt. Orjen, Orjenske lokve - Kabao, [MGRS 34T BN91], Pinus heldreichii zona, krečnjak, 
1500-1893 m, 20.08.2010, coll./det. M. Niketić, G. Tomović (BEOU 31415, BEO s.n.); Mt. Orjen, Pavlović do, [MGRS 34T BN91], šuma Pinus heldreichii, krečnjak, 1750 m, 13.06.2009, coll./det. P. Cikovec (BEOU 29605); Mt. Žijovo, towards to peak, [MGRS 34T CN71], Pinus heldreichii zona, krečnjak, c. 1800 m, 25.08.2011, coll./det. M. Niketić (BEO s.n.).

Note: Although $V$. chelmea subsp. vratnikensis was already known from Mt. Orjen (Degen 1914), the precise locality was not presented, therefore the new records are given in this paper.

Republic of Macedonia: Mt. Jablanica, Crni Kamen, [MGRS 34T DL66], 15.07.1939, coll. P. Černjavski, det. M. Niketić (BEO 8177); Mt. Jablanica, Čuma, padine prema Gornjoj Belici, [MGRS 34T DL66], visokoplaninski kamenjari i pašnjaci, krečnjak, 1700-2100 m, 08.08.2009, coll./det. M. Niketić, G. Tomović (BEO s.n.); Mt. Jablanica, nad Krstec, kon Čumin Vrv, [MGRS 34T DL66], varovnički kamenjar, 1900-2100 m, 04.06.2006, coll./det. Lj. Melovski (MKMEL 00470); Mt. Jablanica, Gorno Labuniško Ezero, [MGRS 34T DL56], karpi (sivi), 1950 m, 19.07.2006, coll. Istražuvačka akcija „Jablanica 2006“, det. Lj. Melovski (MKMEL 08330); Mt. Jablanica, pomeđu Kokalo i Mali Kokal, [MGRS 34T DL66], pasište na kamenjar, varovnik, 1850-1900 m, 15.07.2006, coll. Istražuvačka akcija „Jablanica 2006“, det. Lj. Melovski (MKMEL 08329); Mt. Jablanica, Belička reka - Krstec, [MGRS 34T DL66], pašnjaci i tresave, krečnjak, 1500-1800 m, 18.07.2006, coll./det. M. Niketić, G. Tomović (BEO s.n.); Mt. Jablanica, Malo sedlo, [MGRS 34T DL66], stene i kamenjari, krečnjak, 1958 m, 24.07.2013, coll. M. Niketić, G. Tomović, S. Đurović, U. Buzurović, det. M. Niketić (BEOU 37178, BEO s.n.); Mt. Jablanica, Podgorečko Jezero, okolina, [MGRS 34T DL66], stene, krečnjak, silikat, 1800-1850 m, 18.07.2006, coll./det. M. Niketić (BEOU 21605, BEO s.n.); Mt. Galičica, Tomoros, [MGRS 34T DL83], stene i kamenjari, krečnjak, c. 1600, 23.07.2013, M. Niketić, G. Tomović (pers. obs.); Mt. Galičica, Magaro, ispod vrha, [MGRS 34T DL83], stene i kamenjari, krečnjak, W exp., 10.08.2009, M. Niketić, G. Tomović (pers. obs.); Mt. Bistra, Medenica, [MGRS 34T DM70], stene, rudine i kamenjari, krečnjak, 1800-2163 m, 12.07.2010, M. Niketić, G. Tomović, G. (pers. obs.); Mt. Bistra, Medenica, [MGRS 34T DM71], pasište na kamenjar, varovnik, 1950-2050 m, S exp., 11.06.2004, coll./det. $\mathrm{Lj}$. Melovski (MKMEL 00468); Mt. Bistra, Čaušica, kon Medenica, [MGRS 34T DM70], kamenjar, varovnik, 1900 m, 30.04.2000, coll./det. Lj. Melovski (MKMEL 00467); Mt. Bistra, Čaušica, nad Lakodzere, [MGRS 34T DM71], limestone rocks, 1860 m, 29.05.2008, coll./det. Lj. Melovski (MKMEL 08334); Mt. Bistra, Carevec, [MGRS 34T DM71], limestone stony site, 1670-1730 m, 05.06.2012, coll./det. Lj. Melovski (MKMEL 08326); Mt. Bistra, Kjurkov Dol, [MGRS 34T DM70], pasište na kamenjar, varovnik, $1900-2100 \mathrm{~m}, 31.05 .2006$, coll./det. $L j$. Melovski (MKMEL 00466).

Note: Although $V$. chelmea subsp. vratnikensis was cited for Mt. Jablanica (https://de.wikipedia.org/wiki/Viola_chelmea) and Mt. Galičica (Micevski 1995), the precise localities were not presented, therefore the new records are also given in this paper.

Albania: Mali i Polisit, Lugu i Thellë, Maja Faqja e Madhe, [MGRS 34T DL44], crevices in limestone rocks, 1900-1970 m, 04.07.2008, coll./det. $\mathrm{Lj}$. Melovski (MKMEL 08332, 08333); Albanian Alps (Prokletije), Popllukes, from Kukaj towards Maja e Jezerces, [MGRS 34T DM09], limestone scree and stony site with sparse and stunted Bosnian pines and other shrub, 1500-1600 m, 05.07.2015. coll. Lj. Melovski, N. Melovska, det. Lj. Melovski (MKMEL 08323); 
District of Berat: on the eastern slope of Mali i Tomorit, above village Bargullas, 40.65082 N, 20.15758 E, [MGRS 34T DL20], on limestone rocks, 2232 m, 20.06.2012, coll./det. Z. Barina, D. Pifkó, G. Lunk (BP 21413); District of Bulqizë: Mali i Kreshtës, c. $1.0 \mathrm{~km}$ west of village Vajkal Bulqizë, $41.50809 \mathrm{~N}$, $20.20141 \mathrm{E}$, [MGRS 34T DL39], in grased grassland, on serpentine, $997 \mathrm{~m}$, 30.05.2008, coll./det. Z. Barina, D. Pifkó, B. Pintér (BP 13673); Mali i Kreshtës, on southern slope of Maja e Kreshtes $(2100.9 \mathrm{~m})$, c. $1.2 \mathrm{~km}$ northwest of village Vajkal Bulqizë, 41.51949 N, 20.20548 E, [MGRS 34T DL39], in open grassland, serpentine, $1188 \mathrm{~m}, 01.06 .2008$, coll./det. Z. Barina, D. Pifkó, B. Pintér (BP s.n.); Mali i Lopës, c. $900 \mathrm{~m}$ east of town Bulqizë, towards lake "Liqeni i Zi", 41.49134 N, 20.23671 E, [MGRS 34T DL39], in pine forest, on serpentine, 1057 m, 24.05.2008, coll./det. Z. Barina, D. Pifkó, B. Pintér (BP 13406); District of Burrel: Mali i Dejës, above village Macukull, near pass "Shkol-Den", 41.68929 $\mathrm{N}, 20.16825 \mathrm{E}$, [MGRS 34T DM31], in rocky grassland, on limestone, $1996 \mathrm{~m}$, 09.08.2009, coll./det. Z. Barina, D. Pifkó (BP 15984); District of Devoll: near the summit of Mt. Gremnja, above village Vernik, $40.6644 \mathrm{~N}, 21.0541 \mathrm{E}$, [MGRS 34T EL00], in dolina, on limestone, $1467 \mathrm{~m}, 25.06 .2015$, coll./det. Z. Barina (BP 27976); District of Dibër: Mt. Ruja e Lura, above village Fushë Lurë, 41.78203 N, 20.24341 E, [MGRS 34T DM32], on limestone rocks, $1781 \mathrm{~m}$, 21.06.2013, coll./det. Z. Barina, D. Pifkó (BP 22550); on the E slope of Mts Lajë, c. $6 \mathrm{~km} \mathrm{~N}$ of village Qafë-Murrë and c. $7 \mathrm{~km} \mathrm{~S}$ of village Çidhnë, 41.69699 $\mathrm{N}, 20.21471 \mathrm{E}$, [MGRS 34T DM31], in rocky grassland, on limestone, $1790 \mathrm{~m}$, 19.05.2010, coll./det. Z. Barina, D. Pifkó (BP 17004); District of Has: Maja e Gajrepit, above village Lushaj, 42.21055 N, 20.46392 E, [MGRS 34T DM57], in dry grassland, on serpentine, $1120 \mathrm{~m}, 30.06 .2015$, coll./det. Z. Barina, K. Baráth, G. Puskás (BP 28115); near the peak of Mt. Pashtrik (1998 m), above village Pogaj, 42.20426 N, 20.52563 E, [MGRS 34T DM67], in mountain grassland, on limestone, $1741 \mathrm{~m}, 22.05 .2010$, coll./det. Z. Barina, D. Pifkó (BP 17175); District of Kolonjë: western slope of Mt. Kameniku (2043.1 m), $900 \mathrm{~m}$ west of the peak, $40.2135 \mathrm{~N}, 20.70494 \mathrm{E}$, [MGRS 34T DK75], in limestone rocky grassland, 1890 m, 21.07.2006, coll./det. Z. Barina, D. Pifkó, G. Király, Cs. Németh (BP 10250); District of Kukës: on the slope of Mt. Maja e Marjathit. above village Kalimash, 42.05445 N, 20.29232 E, [MGRS 34T DM45], in grassland, on serpentine, 1016 m, 01.08.2013, coll./det. Z. Barina, D. Pifkó, H. Mező (BP 22954); District of Lezhë: on the slope of Mt. Guri i Kuq, above village Fregën, 41.86162 N, 19.73641 E, [MGRS 34T CM93], in opened grassland, on serpentine, 573 m, 30.03.2015, coll./det. Z. Barina, D. Pifkó, L. Lökös (BP s.n.); on the slope of Mt. Guri i Kuq, above village Fregën, 41.86252 N, 19.73652 E, [MGRS 34T CM93], in opened grassland, on serpentine, $586 \mathrm{~m}, 30.03 .2015$, coll./det. Z. Barina, D. Pifkó, L. Lökös (BP 24373); District of Librazhd: Mali i Jablanices, between Mt. Maja e Strapit (1974 m) and pass Tamizit, c. $5.6 \mathrm{~km}$ south of village Steblevë, $41.28594 \mathrm{~N}, 20.48201 \mathrm{E}$, [MGRS 34T DL57], on gravel-conglomerate rock, 1921 m, 03.07.2008, coll./det. Z. Barina, D. Pifkó, A. Vojtkó (BP 13896); Mali i Jablanices, on Mt. "Lapë" $(2038 \mathrm{~m})$, c. $5.1 \mathrm{~km}$ east of village Qarrishtë, $41.24944 \mathrm{~N}, 20.50152 \mathrm{E}$, [MGRS 34T DL56], in rocky grassland, on limestone, $1840 \mathrm{~m}, 04.07 .2008$, coll./det. Z. Barina, D. Pifkó, A. Vojtkó (BP s.n.); Mali i Jablanices, on Mt. "Lapë" $(2038 \mathrm{~m})$, c. $5.2 \mathrm{~km}$ east of village Qarrishtë, $41.25083 \mathrm{~N}, 20.50372 \mathrm{E}$, [MGRS 34T DL56], in rocky grassland, on limestone, 1998 m, 04.07.2008, coll./det. Z. Barina, D. Pifkó, A. Vojtkó (BP s.n.); Mali i Jablanices, on Mt. "Lapë" $(2038 \mathrm{~m})$, c. $5.6 \mathrm{~km}$ east of village Qarrishtë, $41.24845 \mathrm{~N}, 20.50545 \mathrm{E}$, [MGRS 34T DL56], in rocky grassland, on limestone, 1993 m, 04.07.2008, coll./det. Z. Barina, D. Pifkó, A. Vojtkó (BP 13951); Mali i 
Jablanices, on the $1957 \mathrm{~m}$ high mount between Mt. "Lapë" (2038 m) and Mt. "Zrinos" (1998 m), c. 4.6 km east of village Qarrishtë, 41.25273 N, 20.49773 E, [MGRS 34T DL56], in rocky grassland, on limestone, $1925 \mathrm{~m}, 04.07 .2008$, coll./det. Z. Barina, D. Pifkó, A. Vojtkó (BP s.n.); District of Malësi e Madhe: above village Lëpushë, cliffs Shkëmbejt e Jamës, 42.50204 N, 19.74179 E, [MGRS 34T CN90], on limestone rocks, $1861 \mathrm{~m}, 02.08 .2011$, coll./det. Z. Barina, G. Somogyi (BP 19680); above village Lëpushë, on the ridge between peaks Maja e Mridzit (1952.3 m) and Maja e Berizhdolit, 42.50666 N, 19.71534 E, [MGRS 34T CN90], in $\mathrm{N}$ faced mountain grassland, $1976 \mathrm{~m}, 02.08 .2011$, coll./det. Z. Barina, G. Somogyi (BP 19659); Bjeshkët e Nemuna, above the valley of brook përroi i Runicës, towards pass Vogl, 42.46766 N, 19.78483 E, [MGRS 34T DN00], at the margin of beech forest, on limestone, $1561 \mathrm{~m}$, 16.07.2010, coll./det. Z. Barina, G. Puskás, B. Sárospataki (BP s.n.); Bjeshkët e Nemuna, above village Bogë, between pass qafa e Mushkut and pasture Surta e Bogës, 42.43427 N, 19.6993 E, [MGRS 34T CM99], on limestone rocks, 1915 m, 13.07.2010, coll./det. Z. Barina, G. Puskás, B. Sárospataki (BP s.n.); Bjeshkët e Nemuna, above village Bogë, $\mathrm{N}$ of peak of Mt. Maja e Dragomirit (1901.6 m) and NE of peak Mt. Maja e Borës (1780 m), 42.40866 N, 19.61152 E, [MGRS 34T CM89], in Bosnian pine forest, on limestone, $1618 \mathrm{~m}, 07.12 .2010$, coll./det. Z. Barina, D. Pifkó, G. Puskás, B. Sárospataki (BP s.n.); Bjeshkët e Nemuna, above village Nikç, near homestead Dobrançës, at the foot of Mt. Maja e Shnikut (2552.2 m), $42.46061 \mathrm{~N}, 19.73384 \mathrm{E}$, [MGRS 34T CN90], on carric limestone rocks, 1818 m, 15.07.2010, coll./det. Z. Barina, G. Puskás, B. Sárospataki (BP s.n.); Bjeshkët e Nemuna, between villages Bogë and Nikç, $N$ of pasture Surta e Bogës, at tarn liqeni i Bogës, 42.45071 N, 19.71095 E, [MGRS 34T CN90], in rocky grassland, on limestone, $1822 \mathrm{~m}, 14.07 .2010$, coll./det. Z. Barina, G. Puskás, B. Sárospataki (BP s.n.); Bjeshkët e Nemuna, between villages Bogë and Nikç, $\mathrm{N}$ of pasture Surta e Bogës, near tarn liqeni i Bogës, 42.45114 N, 19.71193 E, [MGRS 34T CN90], on limestone rocks, $1729 \mathrm{~m}, 14.07 .2010$, coll./det. Z. Barina, G. Puskás, B. Sárospataki (BP 17887); on the slope of Mt. Maja e Trojanit (2194.3 m) S of pass qafa e Trojanit, $42.53563 \mathrm{~N}, 19.74561 \mathrm{E}$, [MGRS 34T CN91], in mountain grassland, $2015 \mathrm{~m}, 03.08 .2011$, coll./det. Z. Barina, M. Rakaj, G. Somogyi (BP 19706); District of Mat: Mali i Skënderbeut, on the eastern slope of Mt. Maja e Liqenit $(1722.8 \mathrm{~m}), 41.5389 \mathrm{~N}, 19.89664 \mathrm{E}$, [MGRS 34T DL09], along a brooklet, on serpentine, $1256 \mathrm{~m}, 24.06 .2012$, coll./det. Z. Barina, D. Pifkó, G. Lunk (BP 21546); District of Mirditë: on the eastern ridge of Mali i Munellës, above village Domgjon, 41.98745 N, 20.12107 E, [MGRS 34T DM24], near snow patches, on limestone, $1621 \mathrm{~m}, 25.05 .2010$, coll./det. Z. Barina, D. Pifkó (BP 17368); District of Pukë: on the plateau of Mali i Munellës, $41.96498 \mathrm{~N}$, $20.09384 \mathrm{E}$, [MGRS 34T DM24], in rocky grassland, on limestone, $1812 \mathrm{~m}$, 11.08.2009, coll./det. Z. Barina, D. Pifkó (BP 16025); on the western slope of Mali i Munellës, 41.96695 N, 20.09137 E, [MGRS 34T DM24], in limestone scree, $1674 \mathrm{~m}, 11.08 .2009$, coll./det. Z. Barina, D. Pifkó (BP s.n.); District of Shkodër: Bjeshkët e Nemuna, between Theth and Rragam, southeastern ridge of Mt. "Maja e Alisë" (2471 m), near Pass "qafa e Valbonës", 42.40733 N, 19.80864 E, [MGRS 34T DM09], in beech forest, $1789 \mathrm{~m}, 02.06 .2005$, coll./det. Z. Barina (BP 8155); Bjeshkët e Nemuna, c. $3 \mathrm{~km}$ north of village Okol, Pass Pejes, near the foot of Mt. "Maja e Harapit" (2216.5 m), 42.44094 N, 19.77551 E, [MGRS 34T CM99], on limestone, $1734 \mathrm{~m}, 31.05 .2005$, coll./det. Z. Barina (BP 8100); Bjeshkët e Nemuna, c. $3.5 \mathrm{~km}$ north of village Okol, north of Pass Pejes, near the foot of Mt. "Maja e Harapit" (2216.5 m), 42.4439 N, 19.77189 E, [MGRS 34T CM99], on limestone, 1709 m, 31.05.2005, coll./det. Z. Barina, D. Pifkó (BP 
8118); District of Tiranë: at the peak of Mt. Maja Noj i Madh, above village Bizë, in rocky grassland, 41.35907 N, 20.16812 E, [MGRS 34T DL37], on limestone, 1847 m, 22.06.2012, coll./det. Z. Barina, D. Pifkó, G. Lunk (BP 21463); District of Tropojë: between villages Viçidol and Kasaj, on the W ridge of Mt. Maja e Urishtës, 42.3971 N, 20.18676 E, [MGRS 34T DM39], in opened grassland, on serpentine, $433 \mathrm{~m}, 11.07 .2011$, coll./det. Z. Barina, A. Kovács, G. Puskás, B. Sárospataki (BP 19624); S slope of Mt. Maja e Gjarpnit (2209.7), below homestead Gjarpnit a Poshtme, above village Dragobi, $42.45793 \mathrm{~N}$, $19.98886 \mathrm{E}$, [MGRS 34T DN10], in rocky grassland, on limestone, $1816 \mathrm{~m}$, 11.07.2011, coll./det. Z. Barina, A. Kovács, G. Puskás, B. Sárospataki (BP 19598); at Qafa e Vozit, above village Luzhë, 42.33074 N, 20.17895 E, [MGRS 34T DM38], in dry grassland, on serpentine, $686 \mathrm{~m}, 13.05 .2014$, coll./det. Z. Barina, $D$. Pifkó (BP 23535); c. 500 m WSW of village Sinanaj, 42.31004 N, 20.18376 E, [MGRS 34T DM38], on serpentine rocks, $707 \mathrm{~m}, 11.08 .2012$, coll./det. Z. Barina, G. Somogyi (BP 21879); Bjeshkët e Nemuna, west of town Bajram Curri (Kolgecaj), on Mt. Maja e Dhive (2333 m), 42.35921 N, 19.97989 E, [MGRS 34T DM19], in rocky grassland on limestone, $2188 \mathrm{~m}, 31.05 .2009$, coll./det. Z. Barina, G. Lunk, D. Pifkó, D. Schmidt (BP 15213); Bjeshkët e Nemuna, west of town Bajram Curri (Kolgecaj), on the $1967 \mathrm{~m}$ high mount above pass "qafa e Veshit", $42.3511 \mathrm{~N}, 19.9711 \mathrm{E}$, [MGRS 34T DM18], in rocky grassland, on limestone, 1965 m, 01.06.2009, coll./det. Z. Barina, D. Schmidt (BP 15244); Bjeshkët e Nemuna, west of town Bajram Curri (Kolgecaj), on the southern slope of Mt. Cukali (2067 m), 42.35134 N, 19.99629 E, [MGRS 34T DM18], on limestone rocks, $1887 \mathrm{~m}, 01.06 .2009$, coll./det. Z. Barina, G. Lunk, D. Pifkó, D. Schmidt (BP s.n.); Bjeshkët e Nemuna, west of town Bajram Curri (Kolgecaj), on the southern slope of Mt. Cukali (2067 m), 42.35169 N, 19.99259 E, [MGRS 34T DM18], on limestone rocks, $2000 \mathrm{~m}, 01.06 .2009$, coll./det. Z. Barina, G. Lunk, D. Pifkó, D. Schmidt (BP 15237); near pass qafa e Droçës, above homestead stanet e Droçës, above village Dragobi (Hajdaraj), 42.39805 N, 19.9407 E, [MGRS 34T DM19], in rocky grassland, on limestone, $1700 \mathrm{~m}, 21.07 .2012$, coll./det. Z. Barina, G. Puskás, B. Sárospataki, L. Somay (BP 21689); near pass qafa e Droçës, above village Curraj i Epërm, 42.3869 N, 19.93472 E, [MGRS 34T DM19], in pine forest, on limestone, $1893 \mathrm{~m}, 25.07 .2012$, coll./det. Z. Barina, G. Puskás, B. Sárospataki, L. Somay (BP s.n.); next to village Kam, above the valley of brooklet Maljav, 42.27393 N, 20.22418 E, [MGRS 34T DM38], in semi-dry grassland, on serpentine, $584 \mathrm{~m}, 03.06 .2009$, coll./det. Z. Barina, G. Lunk, D. Pifkó, $D$. Schmidt (BP 15395); on the northern slope of Mt. Maja e Ershelit, above village Peraj, 42.295 N, 19.85511 E, [MGRS 34T DM08], in closed grassland, on limestone, $1862 \mathrm{~m}, 15.07 .2014$, coll./det. Z. Barina, L. Papp, B. Sárospataki (BP 24009); upper part of the valley of brooklet përroi i Bardhe, above village Peraj, $42.33172 \mathrm{~N}, 19.86073 \mathrm{E}$, [MGRS 34T DM08], in rocky grassland, on limestone, $1121 \mathrm{~m}, 18.07 .2014$, coll./det. Z. Barina, L. Papp, B. Sárospataki (BP 24085); west of village Bytyç, on the northern slope of mount above pass "qafa e Luzhës" (815 m), 42.32023 N, 20.16693 E, [MGRS 34T DM38], in burned scrub forest, on serpentine, $881 \mathrm{~m}, 03.06 .2009$, coll./det. Z. Barina, D. Pifkó, D. Schmidt (BP 15341).

\section{HABITAT AND ECOLOGY}

$V$. chelmea subsp. chelmea inhabits limestone rocks and rocks crevices, in scattered Abies cephalonica and Pinus nigra forests or above timberline, at altitudes from (1300-)1400 to 2200 m (Raus 1986, Tan \& Iatrou 2001). 
The other subsp. vratnikensis in the Republic of Macedonia also grows on limestone rocky ground from 1700-2000 m (Micevski 1995), but can be found on much lower altitudes (c. $500 \mathrm{~m}$ ) on ultramafic rocky grounds in Albania (see new records). In the western parts of its distribution range, subsp. vratnikensis inhabits lower to moderate altitudes $(500-1900 \mathrm{~m})$, exclusively on limestone, within open grassy habitats, rocky grounds and rocks. It can rarely be found in shrub communities of Pinus mugo or dry Pinus heldreichii or Pinus nigra forests (Lubarda 2013, Nikolić et al. 2015).

Serbian population on Mts Šar-planina (Mt. Ošljak, Popovo Prase peak) was found at the altitude between 1800 to $1900 \mathrm{~m}$ in the zone of Bosnian Pine forest (Seslerio autumnalis-Pinetum heldreichii Janković et Bogojević 1962). The prime habitat for the species is xerophytic rocky subalpine pastures (Sesleria wettsteinii-Onobrychis montana Rajevski 1990) of the alliance Seslerion rigidae, order Seslerietalia juncifolia and vegetation class Elyno-Seslerietea. Plants grows at S exposure and inclination between 0 to $60^{\circ}$. Geological substrate is limestone. Detailed floristic characteristics of two stands are represented in the following layer:

Herb and shrub layer: Sesleria wettsteinii Dörfl. \& Hayek, Carex humilis Leyss., Seseli rigidum Waldst. \& Kit., Koeleria lobata (Bieb.) Roem. \& Schult., Euphorbia myrsinites L., Jurinea polycephala Formánek, Carex sempervirens Vill., Laserpitium zernyi Hayek, Daphne oleoides Schreb., Eryngium palmatum Pančić \& Vis., Helianthemum canum (L.) Baumg., Silene saxifraga L., Dianthus integer Vis., Asyneuma limonifolium (L.) Janch., Silene otites (L.) Wibel, Dianthus sylvestris Wulfen, Linaria peloponnesiaca Boiss. \& Heldr., Onobrychis montana subsp. scardica (Griseb.) P.W. Ball, Onobrychis alba subsp. laconica (Orph. ex Boiss.) Hayek., Knautia csikii Jáv. \& Szabó.

\section{CHROMOSOME NUMBER}

$2 \mathrm{n}=20$ was reported from Mt. Giona, Mt. Chelidon, and Mt. Kalliakouda in Greece (Franzén \& Gustavsson 1983: 105).

\section{POPULATION SIZE AND AREA OF OCCUPANCY IN SERBIA}

Population area occupies ca. 5 ha, between 1880 and $1920 \mathrm{~m}$. Population size is estimated to be less than 200 mature individuals.

\section{ESTIMATED THREATENED STATUS IN SERBIA}

According to the IUCN (2012) the main level of threat should be regarded as critically endangered: CR B1 i, ii, iv; C2b / EN C2a; D / VU E. 
Viola jooi Janka, Österr. Bot. Wochenbl. 7: 198 (1857)

$\equiv$ V. macroceras subsp. jooi (Janka) Kupffer. Fl. Caucas. Crit. 3: 221 (1909).

$=V$. transsilvanica Schur, Oesterr. Bot. Z. 10: 184 (1860).

\section{DESCRIPTION}

Perennial plant with creeping rhizome, without stolons, 5-8 cm high during the flowering and elongating in fruit. Stems absent. Basal leaves of flowering plants are up to $5 \mathrm{~cm}$ long and $3 \mathrm{~cm}$ wide, extending from the roots, triangular-ovate, cordate-dentate, with a blunt or short pointed tip, with short or fairly deep sinus, on the edge crenate, naked, with long petioles (Figs 6-7). Stipules for almost its entire length adnate to petiole, apex free, linear-lanceolate or lanceolate, acute. Peduncles up to $15 \mathrm{~cm}$ long, with bracts 4-6 $\mathrm{mm}$ long about middle. Flowers moderate to fairly large, 1.5-2.5 cm long and 1.5-2.5 wide, violet or purplish-violet with dark violet or dark purple stripes (in Serbia white with pale yellow stripes), often yellowish at base, fragrant. Sepals 5-6 mm long, 2-2.5 mm wide, elongateelliptical or ovate-lanceolate, obtuse or rounded at apex, appendages short, obtuse or rounded, glabrous. Petals 10-12 $\mathrm{mm}$ long, subrotundate to ovate, \pm crenate, lateral bearded. Spur rather slender, scarcely curved upward or almost straight, pale violet or whitish (in Serbia white), 4-6 mm long. Ovary glabrous; style nail-shaped, thickened toward summit. Capsule 7-9 $\mathrm{mm}$ long, up to $4 \mathrm{~mm}$ wide, ellipsoid, obtuse, glabrous. Seeds large, brown or reddish-brown. Flowering period: April-June.

\section{TAXONOMIC MEMBERSHIP}

Viola [sect. Viola] subsect. Adnatae (W. Becker) W. Becker, Acta Horti Gothob. 2: 285 (1926). - Typus: Viola purpurea Stev.

$\equiv V$. [infragen. unranked] subsect. Adnatae W. Becker, Nat. Pflanzenfam. ed. 2, 21: 36 (1925) [basion.] $\equiv V$. subsect. Adnatae (W. Becker) C.J. Wang, Fl. Reipubl. Popularis Sin. 51: 41 (1991).

$=V$. subg. Violidium C. Koch, Linnaea 15: 251 (1841) $\equiv V$. sect. Violidium (C. Koch) Juz., Fl. URSS 15: 408 (1949), comb. inval. $\equiv V$. subsect. Violidium (C. Koch) P.Y. Fu, Fl. Pl. Herb. Chin. Bor.-Orient. 6: 93 (1977), comb. inval.

$V$. jooi belongs to $V$. subsect. Adnatae (W. Becker) W. Becker, which includes acaulescent perennials plants, without stolons; rhizome branched underground and under the original location of the leaves forming a smooth roots; stipules, especially outer, up to the middle connate (semi-adnate) to petiole, pale green to brown; leaves narrow to wide, at base cuneate to deeply cordate, sometimes like an arrow; style flattened at the top and usually bordered, with short stigma's beak (Becker 1925). In the Flora 


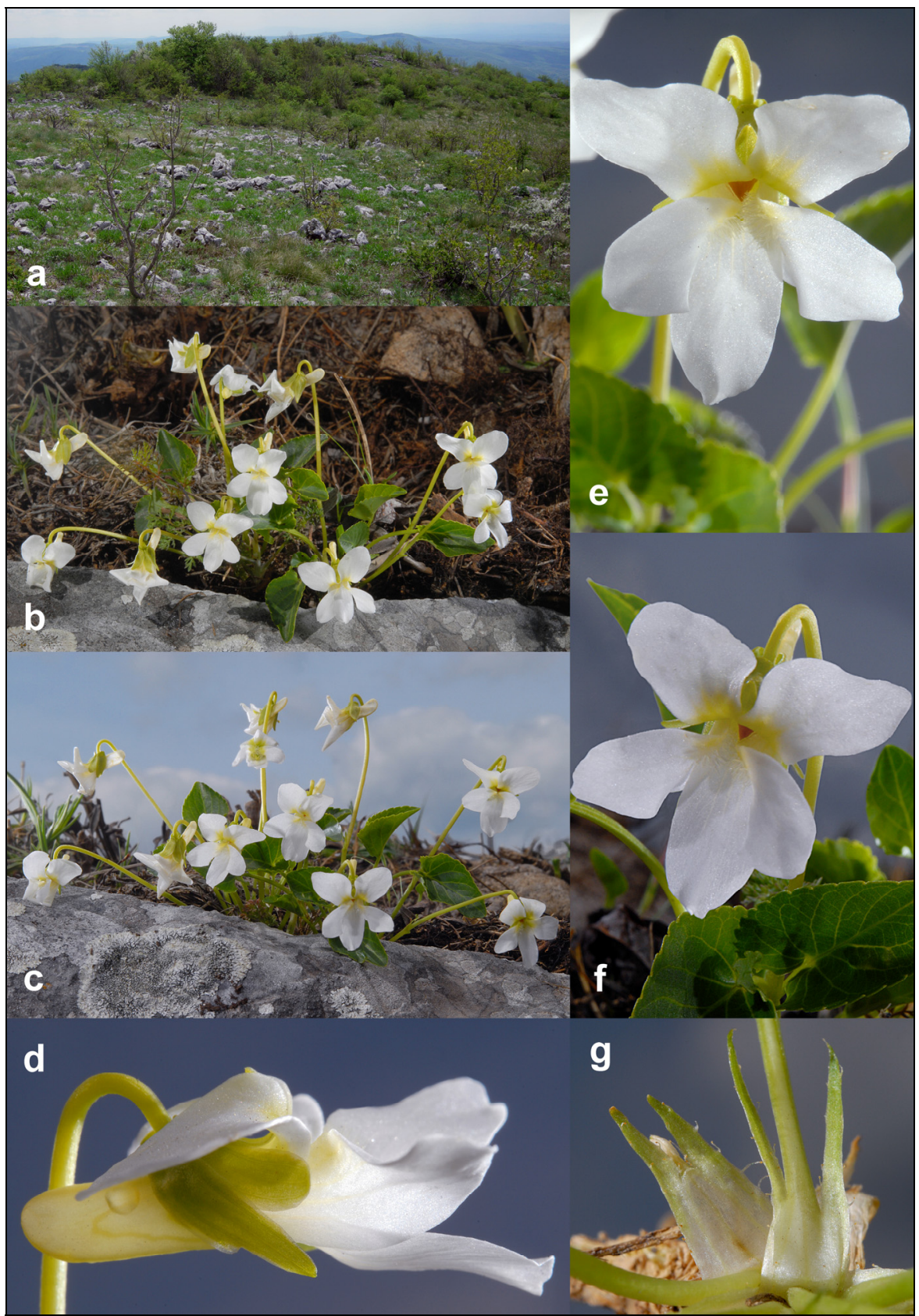

Fig. 6. - Viola jooi Janka: a) Mt. Veliki Vukan (NW Serbia) - species habitat; b-c) habitus; d-f) flowers; g) petioles and stipules (photo M. Niketić).

Europaea, besides $V$. jooi, $V$. subsect. Adnatae encompasses $V$. selkirkii Pursh ex Goldie (distributed in Fennoscandia, N. \& C. Russia) and $V$. 
pinnata L. (present in the Alps) (Valentine et al. 1968). According to Becker (1925), the closest relative of $V$. jooi is $V$. macroceras Bunge and sometimes it was regarded as a subspecies of the latter. $V$. macroceras is distributed in Kashmir, Kazakhstan, Kyrgyzstan, Mongolia, Russia (W Siberia), Tajikistan and Uzbekistan, where it inhabits alpine meadows, rocks, stony slopes, scrub and banks of streams (Yuzepchuk et al. 1949, Chen et al. 2007).

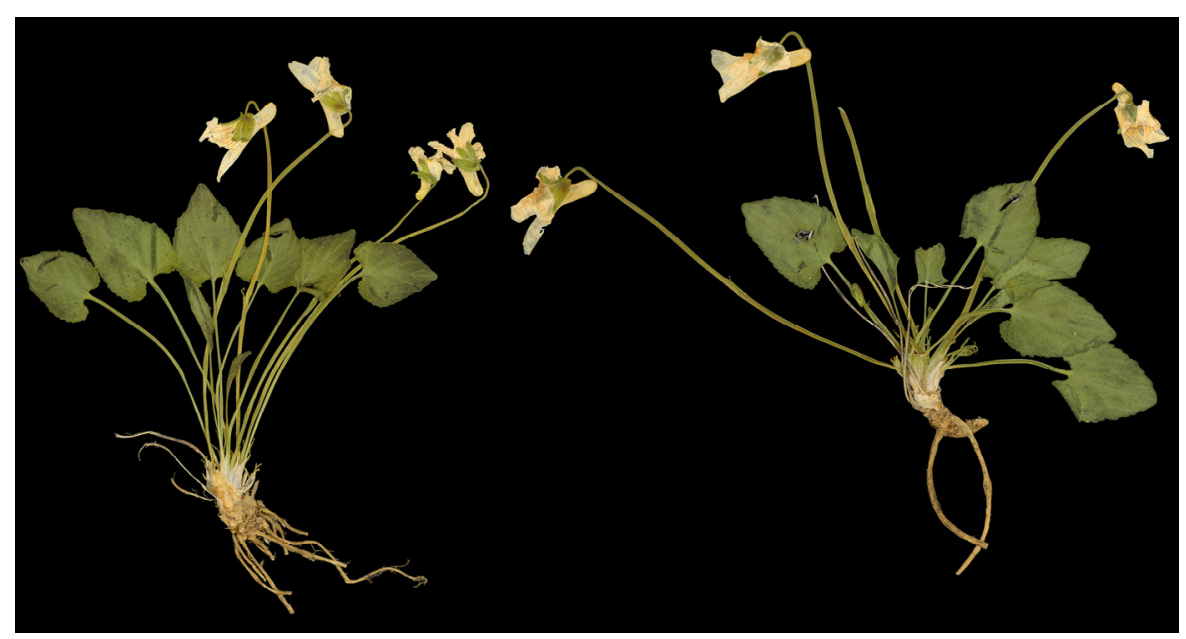

Fig. 7. - Viola jooi Janka - herbarium specimens from Mt. Vukan.

\section{GENERAL DISTRIBUTION}

$V$. jooi is Carpathian endemic plant distributed only in Romania and Ukraine (Fig. 8). In Romania it is present in the following counties and localities: Bacău County (Bicaz pe Piatra Corbului, Bicazu Ardelean, Cheile Bicazului, Mt. Măgura din. V. Bistricioarei, Mții Oituzului pe V. Uzului, Piatra Neamț pe Dl. Cozla, Tulghes), Braşov County (Braşov, Codlea pe Măgura Codlei, Csík Basin, Mt. Piatra Craiului, Mt. Postăvaru, Munții Ciucului, Racoşul de Jos pe Dl. Tipeiului, V. Prăpăstiilor), Cluj County (Cheile Turzii, Cluj la cariera Mănăştur şi pe Dl. Gîbrău, ClujNapoca, Colțeşti, Gîrda, Poiana Aiudului, Poşaga pe Mt. Scăriţa, Rimetea, Vălişoara), Harghita County (Borsec and Frumoasa), Hunedoara County (Hațeg, Hunedoara, Mtii Trăscăului pa Piatra Ceții, Orăştie), Suceava County (Mții Bistriței pe V. Barnarului, Pojorîta pe Mt. Adam şi Eva) and Mehedini County (Domogled - Băile Herculane) (Grințescu et al. 1955). In Ukraine it is distributed in Ivano-Frankivsk region - Tlumach districts (Harasymiv village) and Gorodenky districts (Nazarenkovo village) (Sheliag-Sosonko et al. 1980, Didukh 2009). However, according to Novikoff \& Hurdu (2015) V. jooi in Ukraine belongs to the group of 
doubtful taxa, with its taxonomy and/or chorology under question and in need of further clarifications.

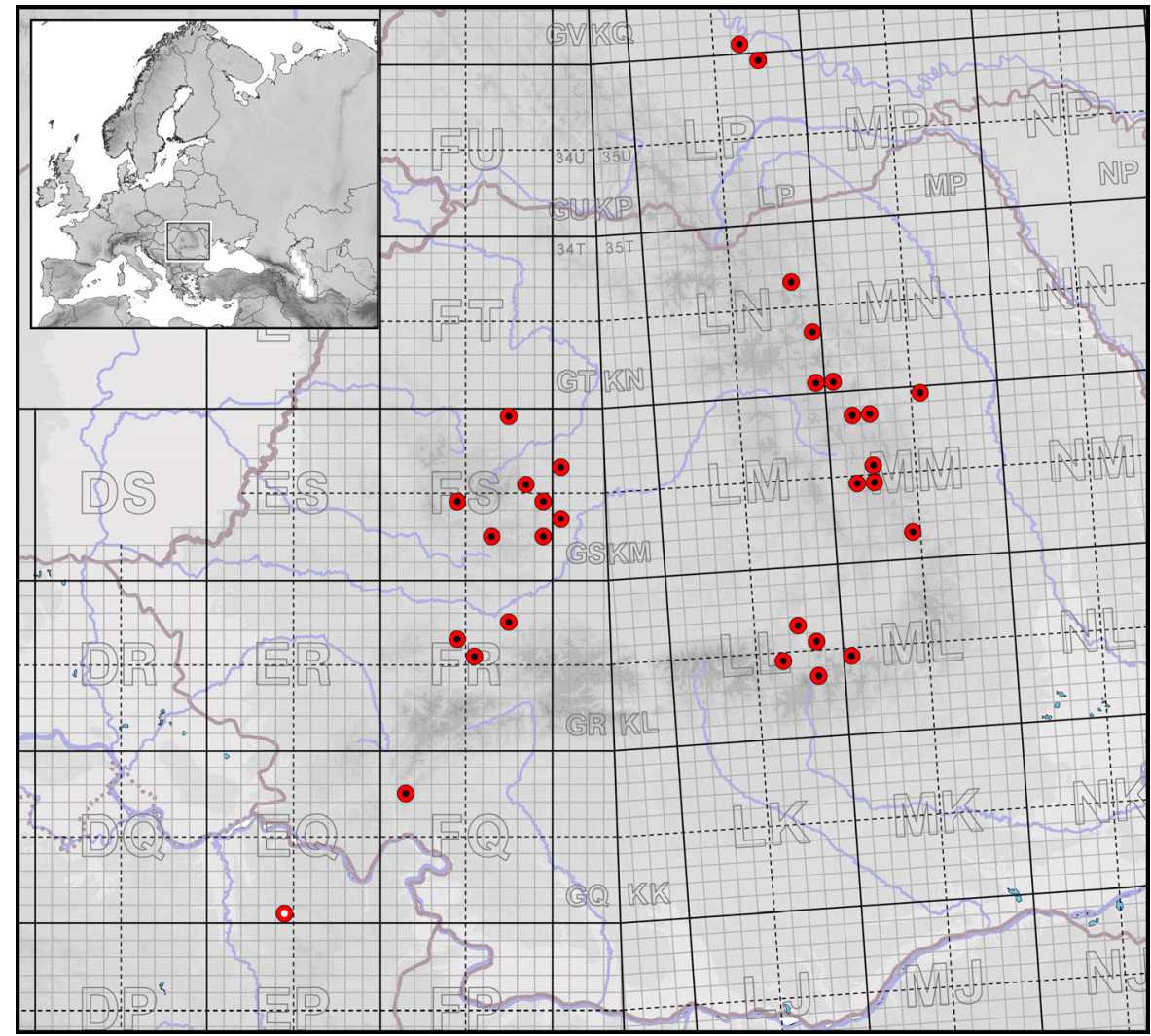

Fig. 8. - Distribution of the species Viola jooi Janka in the Balkan Peninsula and the Carpathians; circle with white spot - according to herbarium new chorological data only; circle with black spot - according to literature data only.

Note: $V$. jooi is on the list of Delivering Alien Invasive Species In Europe (DAISIE), with a status Alien/Not established for Hungary (http://www.europe-aliens.org/) or casual alien (Balogh \& al. 2004, http://www.hear.org/gcw/species/viola_jooi/).

\section{FIRST RECORD IN SERBIA AND THE BALKAN PENINSULA}

Northeast Serbia: Mts Homoljske Planine, Mt. Vukan, Veliki Vukan peak, [MGRS 34T EQ40], stene i kamenjari, krečnjak, c. 810 m, 29.04.2003, coll. M. Niketić, G. Tomović, det. M. Niketić (BEOU 16448; BEO s.n.); stene i kamenjari, krečnjak, c. $820 \mathrm{~m}$, 01.05.2015, coll. M. Niketić, G. Tomović, det. M. Niketić (BEOU 43185; BEO s.n.).

\section{HABITAT AND ECOLOGY}

$V$. jooi grows on limestone rocks and in fissures in mountain regions of the Carpathians (Grințescu et al. 1955). In Romania, it belongs to the group 
of Dacian phytoelements that inhabit rocky grounds of the alliance Seslerion rigidae Zólyómi 1939, order Seslerietalia Br.-B1. 1926 and vegetation class Elyno-Seslerietea Br.-Bl. 1948 (Boşcaiu \& Täuber 1985). In Serbia (at newly established locality in Mt. Vukan) this plant inhabits rocky grounds community Cephalario-Seslerietum rigidae Tatić et Atanacković 1973 of the alliance Seslerion rigidae Zólyómi 1939, order Seslerietalia juncifoliae Ht. 1930 and vegetation class Elyno-Seslerietea Br.-Bl. 1948. Habitat is surrounded by Moesian types of deciduous thickets and scrubs of Syringo-Carpinetum orientalis (Grebenščikov 1950) Mišić 1967 and Eryngio-Syringetum vulgaris Diklić 1965. This plant grows at the altitude between 780 to $820 \mathrm{~m}$, at $\mathrm{S}$ exposure and inclination between 0 to $10^{\circ}$. Geological substrate is limestone. Detailed floristic characteristics of two stands are represented in the following layer:

Herb and shrub layer: Sesleria filifolia Hoppe (= S. rigida Heuff. ex Rchb.), Cephalaria laevigata (Waldst. \& Kit.) Schrad., Seseli rigidum Waldst. \& Kit., Dianthus petraeus Waldst. \& Kit., Viola jooi Janka, Fraxinus ornus L. (seedlings), Crataegus monogyna Jacq., Allium flavum L., Cytisus triflorus Lam.(= C. elongatus Waldst. \& Kit.), Euonymus europaeus L., Erysimum comatum Pančić, Stachys recta L. subsp. recta, Cornus mas L., Iris reichenbachii Heuff., Ceterach officinarum Willd., Teucrium chamaedrys L., Teucrium montanum L., Festuca rupicola Heuff., Carex brevicollis DC., Galium album Mill. subsp. album, Ornithogalum orthophyllum subsp. kochii (Parl.) Zahar., Fragaria viridis Weston, Prunus spinosa L., Viburnum lantana L., Euphorbia cyparissias L., Rosa canina L., Flueggea tinctoria (L.) G.L. Webster (= Rhamnus tinctoria L.).

\section{CHROMOSOME NUMBER}

$2 \mathrm{n}=24$ was reported from Romania (Gershoy 1932, 1934, Valentine et al. 1968)

\section{POPULATION SIZE AND AREA OF OCCUPANCY IN SERBIA}

This plant occurs on restricted area of ca 3 ha $(300 \times 100 \mathrm{~m})$ near the main peak of Mt. Vukan, between 780 to $820 \mathrm{~m}$. Population size is estimated to be less than 500 mature individuals. Continued fouling of rocky pastures could be a major problem for the population survival in the future.

\section{ESTIMATED THREATENED STATUS IN SERBIA}

According to the IUCN (2012) the main level of threat should be regarded as critically endangered: CR B1 i, ii, iv; B2b,c,e / EN C2b / VU C2a; D1; D2; E. 


\section{CONCLUSIONS}

Viola chelmea is a new species from $V$. subsect. Viola for the flora of Serbia. In this paper, 78 new records for the flora of Bosnia and Herzegovina, Montenegro, Albania, Republic of Macedonia and Greece were listed. In addition, the complete distributions of the $V$. c. subsp. vratnikensis and $V$. c. subsp. chelmea in the Balkan Peninsula were presented. Some morphological characters important to subspecific delimitation were also presented for the first time.

Viola jooi represents a new recorded species from $V$. subsect. Adnatae not only for the flora of Serbia, but for the whole Balkan Peninsula. Isolated and very restricted locality of $V$. joo $i$ in Mt. Vukan in northeast Serbia is c. $95 \mathrm{~km}$ distant from the nearest known locality in Romania (Mehedini County, Domogled, Băile Herculane) and marks the southernmost limit of the species distribution range in Europe. It is assumed that the species also occurs in other mountains of northeastern Serbia. It's closest relative, $V$. macroceras, inhabits similar habitats in central Asia. There are not many other examples of remote vicarious species distributed on Balkan Peninsula and C Asia (i.e. Gymnospermium scipetarum Paparisto \& Qosja ex E. Mayer \& Pulević and G. altaicum (Pall.) Spach.) or remote populations of one species with similar distributions (i.e. Sibiraea laevigata (L.) Maxim.). It is interesting to note that Serbian populations are different from all others (incl. V. macroceras) in coloration of petals (white) which can indicate a genetic bottleneck in an isolated population at the far southwest. Further research will show whether a description of a new infraspecific taxon is appropriate.

\section{Acknowledgements}

The authors would like to thank Dr. Bogdan Hurdu (Institute of Biological Research, National Institute for Research and Development in Biological Sciences, Cluj-Napoca, Romania) for the valuable comments and information about $V$. joo $i$ in the Carpathians. The authors are grateful to Snežana Vukojičić, University of Belgrade, Serbia (BEOU); Anis Hasanbegović (SARA), Ernst Vitek, Naturhistorisches Museum Wien, Austria (W); Walter Till and Armin Loeckhe, Universität Wien, Austria (WU) for their help in searching of $V$. prenja type specimens. The Ministry of Education, Science and Technological Development of the Republic of Serbia supported this research through Grant 173030 "Plant biodiversity of Serbia and the Balkans - assessment, sustainable use and protection" and the work of Z. Barina and D. Pifkó was supported by OTKA 104443 grant. 


\section{REFERENCES}

Assyov, B., Petrova, A., Dimitrov, D., Vassilev, R. (2012): Conspectus of the Bulgarian vascular flora. Distribution maps and floristic elements. ed. $4-$ Bulgarian Biodiversity Fondation, Sofia.

Bağc1, Y., Dinç, M., Öztürk, M. (2008): Morphological, Anatomical and Ecological Study on Turkish Endemic Viola yildirimlii M. Dinç \& Y. Bağc1. International Journal of Natural and Engineering Sciences 2(3): 1-5.

Balogh L., Dancza I., Király G. (2004): A magyarországi neofitonok idődszerü jegyzéke és besorolásuk inváziós szempontból. In: Botta-Dukát, Z., Mihály, B. (eds.): Biologiai Invaziok Magyarorszagon: Ozonnovenyek [Biological Invasions in Hungary: Invasive Plants]: 61-92. - TermészetBÚVÁR Alapítvány Kiadó, Budapest. [in Hungarian]

Barina, Z., Pifko, D. (2007): Albánia flórakutatásának eredményei 2006-2007 [Abstract, p. 210]. In: Lőkös, L. (ed.): A Magyar Bilológiai Tarasaság Botanikai Szakosztályànak Ülési (Activity of the Botanical Section of the H.B.S). - Botanikai Közlemények 94(1-2): 201-210.

Beck, G. (1887): Flora von Südbosnien und der angrenzenden Hercegovina. II. Theil. - Annalen des Naturhistorischen Museums in Wien 2(1): 35-76.

Beck, G. (1901): Die Vegetationsverhältnisse der illyrischen Länder. Verlag von Wilhelm Engelmann. Leipzig.

Beck, G. (1918): Flora Bosne, Hercegovine i bivšeg Sandžaka Novog Pazara. II. dio (8. nastavak). - Glasnik Zemaljskog muzeja u Bosni i Hercegovini 30(1-4): 177-217.

Becker, W. (1910): Violenstudien I. - Beihefte zum Botanischen Centralblatt 26: 1-44.

Becker, W. (1925): Viola L. In: Engler, A., Prantl, K. (eds): Die Natürlichen Pflanzenfamilien 21: 363-376. - Verlag von Wilhelm Engelmann, Leipzig.

Bjelčić, Ž., Šilić, Č. (1971): Karakteristične cvjetnice za hercegovački endemni centar pl. Prenj, Čvrsnica i Čabulja. - Glasnik Zemaljskog muzeja u Bosni i Hercegovini, Nova Serija 10: 39-57.

Boşcaiu, N., Täuber, F. (1985): Die zönologischen Verhältnisse der dazischen und dazisch-balkanischen Arten aus dem rumänischen Karpatenraum. - Vegetatio 59: 185-192.

Botond, M., Zoltán, B.-D. (eds) (2004): Biologiai Invaziok Magyarorszagon: Ozonnovenyek [Biological Invasions in Hungary: Invasive Plants]. TermészetBÚVÁR Alapítvány Kiadó, Budapest. [in Hungary]

Chen, Y.S., Yang, Q.E., Ohba, H., Vladimir, V.N. (2007): Violaceae. In: Wu, Z.Y., Raven, P.H., Hong, D.Y. (eds): Flora of China 13: 74-111. - Science Press, Beijing and Missouri Botanical Garden Press, St. Louis.

Degen, A. (1914): Über das Vorkommen einer Rasse von Viola chelmea Boiss. et Heldr. in Dalmatien und in Kroatien. - Magyar Botanikai Lapok 13: 309-311.

Didukh, Ya.P. (2009): Fialka Dzhoya, Viola jooi Janka. In: Didukh, Ya.P. (ed.): Red book of Ukraine [Червона книга України. Рослинний світ]. In: Plant world: 620. - Globalconsulting, Kyiv. [in Ukrainian] 
Dimopoulos, P., Raus, Th., Bergmeier, E., Constantinidis, Th., Iatrou, G., Kokkini, S., Strid, A., Tzanoudakis, D. (2013): Vascular plants of Greece: An annotated checklist. - Botanischer Garten und Botanisches Museum, Berlin-Dahlem; Hellenic Botanical Society, Athens.

Dinç, M. (2009): Comparative morphological and palynological study on poorly known Viola sandrasea and its closest relative $V$. kizildaghensis. - Biologia 64(1): 81-87.

Dinç M., Yıldırımlı, S. (2002): A new species of Viola (Violaceae) from Turkey. Botanical Journal of the Linnean Society 138: 483-487.

Dinç, M., Bağcı, Y., Yıldırımlı, S. (2003): A New Species of Viola L. (Violaceae) from South Anatolia. - Botanical Journal of the Linnean Society 141: 477-482.

Đug, S., Muratović, E., Drešković, N., Boškalo, A., Dudević, S. (2013): Crvena lista Federacije Bosne i Hercegovine. Nacrt izvještja - Prijedlog. - EU "Greenway", Sarajevo.

Erben, M. (1985): Cytotaxonomische Unterschungen an Sudosteuropaischen Viola-arten der sektion Melanium. - Mitteilungen der botanischen Staatssammlung München 21: 339-740.

Franzén, R., Gustavsson, L.-Å. (1983): Chromosome Numbers in Flowering Plants from the High Mountains of Sterea Ellas, Greece. - Willdenowia 13(1): 101-106.

Gershoy A. (1932): Descriptive notes for Viola exhibits. The Nominium and Chamaemelanium sections. In: Jones, D. F. (ed.): Proceedings $6^{\text {th }}$ International Congress of Genetics (Ithaca, New York): 1-27. - Vermont Agricultural Experiment Station, Burlington.

Gershoy A. (1934): Studies in North American violets III, Chromosome numbers and species characters. - Vermont Agricultural Experiment Station, Bulletin 367: 1-92.

Grințescu, G., Guşuleac, M., Nyárády, E.I. (1955): Violaceae. In: Săvulescu, T. (ed.): Flora Republicii Populare Române 3: 553-625. - Academia Republicii Populare Române, Bucuresti.

Hayek, A. (1918): Beitrag zur Kenntnis der Flora des Albanisch-Montenegrinischen Grenzgebietes. - Kaiserliche Akademie der Wissenschaften in Wien. Mathematisch-Naturwissenschaftliche Klasse. Denkschriften 94: 127-210.

Hayek, A. (1924): Prodromus Florae peninsulae Balcanicae 1. - Repertorium specierum novarum regni vegetabilis. Beihefte 30(3): 353-512.

IUCN (2012): IUCN Red List Categories and Criteria: Version 3.1. Second edition. - IUCN Species Survival Commission,. IUCN, Gland \& Cambridge.

Lampinen, R. (2001): Universal Transverse Mercator (UTM) and Military Grid Reference System (MGRS). (accessed: 10 December 2015) [http:// www.luomus.fi/en/utm-mgrs-atlas-florae-europaeae]

Lubarda, B. (2013): Horološka analiza balkanske endemične flore na teritoriji Bosne i Hercegovine. - Prirodno-matematički fakultet Univerziteta u Banjoj Luci. (PhD Thesis, manuscr.) [in Serbian]

Malý, K. (1923): Prilozi za floru Bosne i Hercegovine 9. - Glasnik Zemaljskog muzeja u Bosni i Hercegovini, Sarajevo 35: 123-162.

Marcussen T., Borgen L. 2000. Allozymic variation and relationships within subsection Viola (Violaceae). - Plant Systematics and Evolution 223: 29-57. 
Marcussen, T. Borgen, L., Nordal, I. (2003): Population Differentiation and Hybridisation in the Greek endemism Viola chelmea ssp. chelmea. In: Marcussen, T. 2003: Violets of the Subgenus Viola in Europe. Variation, Evolution and systematics. Dissertation: 1-8. - Oslo University. (PhD Thesis, manuscr.)

Melchior, H. (1939): Ein neues Veilchen aus SW.-Anatolien und die Phylogenie der Sprossentwiclung innerhalb der Sektion Nomimium. - Feddes Repertorium 46: 39-42.

Micevski, K. (1995): Flora na Republika Makedonija. - Makedonskata akademija na naukite i umetnostite, Skopje. [in Macedonian]

Nikitin, V.V. (2012): Superordo Violanae In: Takhtajan, A.L. (ed.): Caucasian flora conspectus 3(2): 338-349. - Universitatis Petropolitanae, SanktPeterburg. [in Russian]

Nikolić, T. (ed.) (2015): Flora Croatica Database. - University of Zagreb, Faculty of Science, Department of Botany and Botanical garden. Available from: http://hirc.botanic.hr/fcd/. (accessed: 21 July 2015).

Nikolić, T., Milović, M., Bogdanović, S., Jasprica, N. (2015): Endemi u Hrvatskoj flori. - Alfa d.d. Zagreb.

Novikoff, A., Hurdu, B.-I. (2015): A critical list of endemic vascular plants in the Ukrainian Carpathians. - Contribuţii Botanice 50: 43-91.

Okamoto, M., Okada, H., Ueda, K. (1993): Morphology and chromosome number of Viola pilosa and systematic position. - Taxon 42: 781-787.

Qosja, X.H., Paparisto, K., Demiri, M., Vangjeli, J., Balza, E. (1992): Flora e Shqipërisë 2. - Akademia e Shkencave e Republikes se Shqiperise, Qendra e Kerkimeve Biologjike, Tiranë,.

Raus, T. (1986): Viola L. In: Strid, A. (ed.): Mountain Flora of Greece 1: 608-640. - University Press, Cambridge.

Rohlena, J. (1942): Conspectus Florae Montenegrinae. - Preslia 20-21: 1-506.

Rössler, W. (1943): Inhalt und Inhalt und systematische Bedeutung der Phloroglucingerbstoffzellen in den Laubblättern europäischer Viola-Artcn. Wiener botanische Zeitschrift 92: 97-123.

Schmidt, A. (1964): Zur Systematischen Stellung von Viola chelmea Boiss. et Heldr. ssp. chelmea und $V$. delphinantha Boiss. - Berichte der deutschen botanischen Gesellschaft 77: 256-261.

Sheliag-Sosonko, Yu. R., Didukh, Ya. P., Kukovytsa, H. S. (1980): Distribution of Viola jooi Janka in the Ukraine [Поширення Viola jooi Janka на Україні] Ukrainian Botanical Journal 37(3): 221-224. [in Ukrainian]

Shuka, L. (2012): Survey on vegetation of alpine meadows and pastures of the PNP in Albania. - Draft Report. Republic of Albania, Ministry of Environment, Forestry and Water Administration. Tirana.

Šilić, Č., Abadžić, S. (1991): Endemične biljne vrste Dinarida i mogućnosti primjene nekih vrsta u hortikulturi. - Glasnik Zemaljskog muzeja u Bosni i Hercegovini, Nova Serija 30: 47-127.

Tan, K., Iatrou, G. (2001): Endemic plants of Greece. The Peloponnese. - Gads Forlag, København. 
The Plant List (2013): Version 1.1. Published on the Internet (accessed $1^{\text {st }}$ January). [http://www.theplantlist.org/]

Thiers, B. 2013. [continuously updated]. Index Herbariorum: A global directory of public herbaria and associated staff. - New York Botanical Garden's Virtual Herbarium. [http://sweetgum.nybg.org/ih]

Tomović, G., Vukojičić, S., Mirjačić, K., Radović, A., Niketić, M. (2014): Genus Viola L. (Violaceae) in Serbia-Collections of the Natural History Museum in Belgrade and the Institute of Botany and Botanical Garden "Jevremovac", Faculty of Biology, University of Belgrade. - Bulletin of the Natural History Museum in Belgrade 7: 31-91

Trinajstić, I. (1975): Porod. Violaceae. In: Trinajstić, I. (ed.): Analitička flora Jugoslavije 2(1): 34-79. - Institut za botaniku Sveučilišta u Zagrebu, Zagreb. [in Croatian]

Valentine, D.H., Merxmüller, H., Schmidt, A. (1968): Viola L. In: Tutin, T.G., Heywood, V.H., Burges, N.A., Moore, D.M., Valentine, D.H., Walters, S.M., Webb, D.A. (eds): Flora Europaea 2: 270-282. - University Press, Cambridge.

Yuzepchuk, S.V., Klokov, M.V. (1949): Violaceae. In: Shishkin, B.K., Bobrov, E.G. (eds): Flora of the USSR 15: 262-360. - Izdatel'stvo Akademii Nauk SSSR, Moskva-Leningrad.

\title{
VIOLA CHELMEA И VIOLA JOOI(VIOLACEAE), НОВE ВРСТЕ 3А ФЛОРУ СРБИЈЕ И ЊИХОВО РАСПРОСТРАҢЕЊЕ НА БАЛКАНСКОМ ПОЛУОСТРВУ И НА КАРПАТИМА
}

\author{
МАРЈАН НИКЕТИЋ, ПАВЛЕ ЦИКОВАЦ, ЗОЛТАН БАРИНА, ДАНИЕЛ ПИФКО, \\ ЉУПЧО МЕЛОВСКИ, ШЕМИЈА ДУРАКИ, ГОРДАНА ТОМОВИЋ
}

\section{Р Е 3 И М Е}

Током неколико ботаничких експедиција на подручју Србије (Шар-планина и Хомољске планине), откривене су две нове врсте из рода Viola (V. sect. Viola) за флору Србије: Viola chelmea Boiss. \& Heldr. сакупљена је на планини Ошљак, a Viola jooi Janka на планини Вукан. $V$. jooi истовремено представља и нову врсту за флору Балканског полуострва. Таксономски положај, фитогеографски значај и конзервациони статуси ове две нове врсте за подручје Србије дискутовани су у светлу новоуспостављених образаца дистрибуције на Карпатима и на простору Балканског полуострва. 